\title{
Effect of Stress on job satisfaction among nurses in central kerala
}

\author{
Ms. Neenu Ann Mathew
}

\begin{abstract}
Modern life is full of stress. Nursing is, by its very nature, an occupation subject to a high degree of stress. This profession involves working with people who are themselves suffering a considerable degree of stress. The purpose of this paper is to examine job stress and its impact on the job satisfaction among nurses in private hospitals. The survey based instrument was used to gather the responses from the nurses working in leading hospitals having more than 407 beds situated in Central Kerala. Questionnaire was the main tool used to collect the pertinent data from the selected sample respondents. 100 respondents participated in this survey. This study is limited to hospitals. The results may not be applicable to other business organization. The study has been analyzed through simple percentage method and SPSS.
\end{abstract}

Key words: Job Satisfaction, Nurses, Stress

\section{Introduction}

During the past few decades, stress has been given the attention of researchers in many and varied fields. A primary reason why researchers are studying stress lies in the recognition by management that stressrelated problems are reducing productivity and morale. Of all professional groups, nursing has one of the highest rates of suicide and nurses top the list of psychiatric outpatient referrals. Even in training the drop-out rate is extremely high and has been the subject of official government inquiry. An aging workforce along with higher patient acuity, shorter hospital stay, and other workplace changes contribute to job stress. Nursing is, by its very nature, an occupation subject to a high degree of stress. This profession involves working with people who are themselves suffering a considerable degree of stress. Patients are often difficult, frightened and resentful, and nurses can find themselves responding with a growing sense of irritability and frustration. Nurses can easily become disillusioned, cynical, and depressed. This attitude can appropriately be termed nurse "Burnout". Iveson describes "Burnout" as an extension of stress and can be put simply as a depletion of energy experienced by a person when one feels overwhelmed by other people's problems. Once this occurs, the person adopts the apparently cynical attitude of why bother? Unless remedied, the nurse will opt to quite the profession. Much research has been conducted on the individual areas of job stress and job satisfaction. Very little research has been done on correlating these two variables, in attempts to produce reliable, valid information on nursing personnel. Hospital administrators must be able to manage their nursing staff, as well as help the nursing staff to better manage themselves. Otherwise, hospitals will be facing a severe nursing shortage, both quantitatively as well as qualitatively.

\section{Conceptual Framework}

Stress may be defined as "a state of psychological and / or physiological imbalance resulting from the disparity between situational demand and the individual's ability and / or motivation to meet those demands." Stress can be positive or negative. Stress can be positive when the situation offers an opportunity for a person to gain something. It acts as a motivator for peak performance. Stress can be negative when a person faces social, physical, organizational and emotional problems. : It occurs when the person does not known what he is supposed to do on the job. His tasks and responsibilities are not clear. The employee is not sure what he is expected to do. This creates confusion in the minds of the worker and results in stress. Stress may occur to those individuals who work in different shifts. Employees may be expected to work in day shift for some days and then in the night shift. This may create problems in adjusting to the shift timings, and it can affect not only personal life but also family life of the employee. Doing less work or jobs of routine and simple nature would lead to monotony and boredom, which can lead to stress. Employees may be subject to poor working conditions. It would include poor lighting and ventilations, unhygienic sanitation facilities, excessive noise and dust, presence of toxic gases and fumes, inadequate safety measures, etc. All these unpleasant conditions create physiological and psychological imbalance in humans thereby causing stress.

Job satisfaction is defined as "the favorableness or unfavorableness with which employees view their work". Job satisfaction is an effective attitude-a feeling of relative like or dislike toward something. Job satisfaction is generally defined as an employee's affective reaction to a job, based on comparing actual outcomes with desired outcomes. Job satisfaction can be defined as a collection of feelings that an individual holds toward his or her job. 


\section{Sources of stress among Nurses}

Nursing has been identified as a high-stress profession that is not just physically demanding but also emotionally and intellectually demanding ( (Karen Sanders n.d.)) which can translate to stress.

Stress levels will increase when controllability and predictability in a situation decrease. The cause of stress for nurses has found to be related to the nature of the profession. Included in these stressors are an intense work environment with extended work hours, weekends, night and holidays.

The sources of stress includes: time pressure, critical decisions, provider-patient dissonance, patient stress, professional relations the main treatment for reducing the stress are: education, mutual support, control of working hours, orientation of nurses.(Leon Phipps , 1988).

The seven major sources of stress include: dealing with death and dying, conflict with physicians, inadequate preparation to deal with the emotional needs of patients and their families, lack of staff support, conflict with other nurses and supervisors, workload,uncertainity regarding treatment.(Gray-Toft and Anderson). Health care workers suffer from occupational stresses resulting from high expectation coupled with insufficient time, skills, and social support at work. This can lead to severe distress, burnout, and physical illness and finally decrease in quality of life and service provision. The cost of stress and burnout has increased due to absenteeism and turnover. Work stress is increasingly identified as one of the most serious health hazards reducing productivity, satisfaction and increasing absenteeism. ( (N.Muthukrishnan 2011))

\section{The relation between the satisfaction and the stress}

There is an inverse relationship between stress and job satisfaction, as stress goes up, job satisfaction falls. As a result this increased stress could commonly results in decreased job satisfaction and decreased quality of life. This could potentially contribute to nurses leaving the profession and as an end consequence, account for the current nursing shortage. Diminished job satisfaction inevitably results in negative attitude towards one's work, family, patients, colleagues and ultimately, self.

Social support from supervisors and colleagues has a negative association with work stress. Work empowerment also showed a strong and negative association with job tension and a positive association with work effectiveness. Psychological empowerment had a positive effect on job satisfaction and a negative influence on job strain. In the health care organization, work stress may contribute to absenteeism and turnover, both of which detract from the quality of care.( (Jennings 2005))

\section{Steps to reduce and manage stress}

Good management practices are powerful stress management interventions. It includes relevant and relevant staff meeting, structured staff development program me and grading reviews, structured and purposeful staff consultation, job rotation to ensure skill use, giving staff responsibility and freedom to make decisions, experienced help and advice readily available.( (Tom cox 2002))

Psychological empowerment had a positive effect on job satisfaction and a negative influence on job strain.( (Jennings 2005).

\section{Aim and objectives of the study}

The primary aim of the study is to study the impact of stress on the job satisfaction of nurses in Central Kerala.

\section{Objectives of the study}

1. To determine the sources of stress

2. To identify the relation between the satisfaction and the stress

3. To identify how to reduce and manage stress

\section{Research Methodology}

The type of research used for this study was analytical research. The population of our research was the nurses working in hospitals in Central Kerala. The data was collected with the help of questionnaires and interaction with the nurses. The sampling method used is convenient sampling. The sample size is 86.The primary data during the course of study was collected through questionnaire. The secondary data was collected from, Reference books, Magazines and newspapers, Articles from internet etc.

\section{Data analysis and Interpretation}

Analysis and interpretation means analyzing the primary data and interpreting the result. Here, primary data is first collected and it is edited, coded and tabulated to extract useful information. Percentage method and chi -square test is used to analyze the data. Percentage can be calculated by summing up the frequencies of each particular class of interval and taking it as percentage. Graphs are used to represent the information. It helps 
others to easily understand the data analysis and interpretation is the most important part of the project. The sample size of the project includes 86nurses.

\section{Limitation of the study}

1. The study was restricted to the nurses working in Central Kerala only.

2. The sample of 86 is difficult to generalize the results

3. The data collected was through questionnaires and it has its own limitations.

\section{Relation between pay and job satisfaction}

\section{Hypothesis}

$\mathrm{H}_{0}=$ There is no significant relation between pay and job satisfaction $\mathrm{H}_{1}=$ There is a significant relation between pay and job satisfaction

Pay

\begin{tabular}{|l|r|r|r|}
\hline & Observed N & Expected N & Residual \\
\hline 1 & 6 & 17.2 & -11.2 \\
2 & 15 & 17.2 & -2.2 \\
3 & 30 & 17.2 & 12.8 \\
4 & 4 & 17.2 & -13.2 \\
5 & 31 & 17.2 & 13.8 \\
Total & 86 & & \\
\hline
\end{tabular}

Test Statistics

\begin{tabular}{|l|r|}
\hline & \multicolumn{2}{|c|}{ Pay } \\
\hline Chi-Square & $38.302^{\mathrm{a}}$ \\
Df & 4 \\
Asymp. Sig. & .000 \\
\hline
\end{tabular}

a. 0 cells $(.0 \%)$ have expected frequencies less than

5. The minimum expected cell frequency is 17.2.

From the test, $X^{2}(4)=38.302, p \leq 0.05$ (95\% level of significance). Probability obtained is 0.000 which is less than 0.05 .Therefore the null hypothesis is rejected ie, there is a significant relation between pay and job satisfaction.

Relation between job stress and job satisfaction

$\mathrm{H}_{0}=$ There is no significant relation between job stress and job satisfaction $\mathrm{H}_{1}=$ There is a significant relation between job stress and job satisfaction

Job stress

\begin{tabular}{|l|r|r|r|}
\hline & Observed N & Expected N & Residual \\
\hline 1 & 25 & 17.2 & 7.8 \\
2 & 19 & 17.2 & 1.8 \\
3 & 21 & 17.2 & 3.8 \\
4 & 18 & 17.2 & .8 \\
5 & 3 & 17.2 & -14.2 \\
Total & 86 & & \\
\hline
\end{tabular}

Test Statistics

\begin{tabular}{|l|r|}
\hline & \multicolumn{2}{|c|}{ Job stress } \\
\hline Chi-Square & $16.326^{\mathrm{a}}$ \\
Df & 4 \\
Asymp. Sig. & .003 \\
\hline
\end{tabular}

a. 0 cells $(.0 \%)$ have expected frequencies less than

5 . The minimum expected cell frequency is 17.2. 
From the test it is interpreted, $\mathrm{X}^{2}(4)=16.326, \mathrm{p} \leq 0.05$. Level of significance is assumed as $95 \%$. Probability obtained is 0.003 which is less than 0.05 . it is interpreted the null hypothesis is rejected ie, there is a significant relation between pay and job satisfaction.

\section{Relation between stress relief programs and job satisfaction}

$\mathrm{H}_{0}=$ There is no significant relation between stress relief programs and job satisfaction $\mathrm{H}_{1}=$ There is a significant relation between stress relief programs and job satisfaction

stress relief programs

\begin{tabular}{|l|r|r|r|}
\hline & Observed N & Expected N & Residual \\
\hline 1 & 1 & 17.2 & -16.2 \\
2 & 7 & 17.2 & -10.2 \\
3 & 31 & 17.2 & 13.8 \\
4 & 13 & 17.2 & -4.2 \\
5 & 34 & 17.2 & 16.8 \\
Total & 86 & & \\
\hline
\end{tabular}

Test Statistics

\begin{tabular}{|l|r|}
\hline & \multicolumn{2}{|c|}{ stress relief programs } \\
\hline Chi-Square & $49.814^{\mathrm{a}}$ \\
Df & 4 \\
Asymp. Sig. & .000 \\
\hline
\end{tabular}

a. 0 cells $(.0 \%)$ have expected frequencies less than

5. The minimum expected cell frequency is 17.2.

From the test it is interpreted, $\mathrm{X}^{2}(4)=49.814, \mathrm{p} \leq 0.05$. Level of significance is $95 \%$.Probability obtained is 0.000 which is less than 0.05 . it is interpreted the null hypothesis is rejected ie, there is a significant relation between stress relief programs and job satisfaction

\section{Relation between job assistance and job satisfaction}

$\mathrm{H}_{0}=$ There is no significant relation between job assistance and job satisfaction $\mathrm{H}_{1}=$ There is a significant relation between job assistance and job satisfaction

\begin{tabular}{|l|r|r|r|}
\hline \multicolumn{4}{|c|}{ Job assistance } \\
\hline & Observed N & Expected N & Residual \\
\hline 1 & 16 & 17.2 & -1.2 \\
2 & 22 & 17.2 & 4.8 \\
3 & 15 & 17.2 & -2.2 \\
4 & 25 & 17.2 & 7.8 \\
5 & 8 & 17.2 & -9.2 \\
Total & 86 & & \\
\hline
\end{tabular}

\section{Test Statistics}

\begin{tabular}{|l|r|}
\hline & \multicolumn{2}{|c|}{ Job assistance } \\
\hline Chi-Square & $10.163^{\mathrm{a}}$ \\
df & 4 \\
Asymp. Sig. & .038 \\
\hline
\end{tabular}

a. 0 cells $(.0 \%)$ have expected frequencies less than

5. The minimum expected cell frequency is 17.2.

From the test it is interpreted, $\mathrm{X}^{2}(4)=10.163, \mathrm{p} \leq 0.05$. Probability obtained is 0.038 which is less than 0.05 . it is interpreted the null hypothesis is rejected ie, there is a significant relation between job assistance and job satisfaction 


\section{Sources of stress}

\section{Findings}

Nurses are stressed due to the long working hours. The two working shifts include $8 \mathrm{am}-6 \mathrm{pm}$ and $6 \mathrm{pm}-$ $8 \mathrm{am}$. They feel burnout due to the inadequacy of staffs in departments. The staff: patient ratio was found to be 1:5. Almost $96 \%$ has the opinion that they are stressed under their job. Only $12 \%$ of the nurses find their work load can be handled easily. The stress due to work and pressure is about $56 \%$.The other source of stress was found to be working in a depressed environment due to the insufficiency in staff co-ordination and passing the buck during the handing over process. If the stress is rated in a scale about $90 \%$ are stressed above average

\section{Relation between stress and satisfaction}

Only $7 \%$ of the nurses understudy are satisfied with the pay according to the efforts which are put in. Only $29.07 \%$ are satisfied with assistance that they get from the doctors and other staffs. Nurses are highly satisfied with the communication channel prevailing in the organizations. Less than $7 \%$ feel that their job is secured. Only about $15.1 \%$ are happy with the present working environment $15.1 \%$ are satisfied with social support from the peer. About $34.88 \%$ reported psychological harassment from doctors or co-workers to affect their performance

\section{Suggestions}

Flexibility in working hours should be implemented by reducing the shifts to three ie; $7 \mathrm{am}-1 \mathrm{pm}, 1 \mathrm{pm}$ $7 \mathrm{pm}, 7 \mathrm{pm}-7 \mathrm{am}$.Adequate staff should be appointed in departments by implementing a staff-patient ratio of 1:3 so that the work load can be handled easily by the nurses. Nurses have to be provided with good working environment of increased staff co-ordination and one duty should be given at a time. In a ward 5-6 staff will be taking care of 15 patients at a time. This has to be reduced to 2-3 staffs so that there will be a good division of labor. They have to be felt that their job is secured; this can be ensured through attractive salaries. According to law, nurses have to be paid a basic salary of Rs.13000 per month but unfortunately the basic salaries given in most of the hospitals are Rs.6000-7000. They have to provided with an opportunity to continue their education through add on courses and certifications on job which also can decrease the threat of job insecurity among nurses. They should be given an opportunity for participating in cultural and other entertainment activities. They have to be given good counseling to cope up with the stress at work once in a week. Tiring paper works has to be distributed to administrative departments. Nurses should be engaged in stress relief programs like Yoga, exercise, etc. The hours of work per week should be reduced to 30-45 hours.

\section{Conclusion}

Form the study conducted, the stress has a negative relationship with satisfaction. As stress goes up, job satisfaction falls. The increased stress could commonly results in decreased job satisfaction and decreased quality of life. This could potentially contribute to nurses leaving the profession and as an end consequence, account for the current nursing shortage The various sources of stress indentifies include: pressure at work, work environment, work schedule, much of paper works, job insecurity, long working hours and inadequacy of staff in each department. The stress can be managed through implementing various stress relief programs, by holding counseling once in every month, by providing adequate leave and holidays.

\section{Bibliography}

[1] B, Mc Gowan. "self reported stress and its effect on nurses." Nursing standard, september 2001: 33-38.

[2] Brunero, Scott. "stress management for nurses." NSW Health. 2006. http://www.nswnurses.asn.au/ (accessed october 12, 2012).

[3] Eleni Moustaka, Theodoros C Constatinidis. "Sources and effects of work-related stress in nursing." Health Science Journal, 2010: 210-216

[4] Jennings, Bonnie M. Work stress and burnout among nurses:Role of work environment and working conditions. 2005.

[5] Karen Sanders, Lucia Thornton and Jeanne Crawfor. Reality of stress in nursing workplace. http://www.ahna.org/Resources/StressManagement/tabid/1229/Default.aspx (accessed october 14, 2012).

[6] Kathleen Whitmer, Akron, Ohio. ways to cope with stress. 2007. http://www.holisticonline.com/stress/stress_ways-to-copewhitmer.htm (accessed october 10, 2012)

[7] N.Muthukrishnan, Sajimon MR,Dr.D.S.Chaubey. "Factors driving occupational stress of employees working in hospital in Dehradun." International Journal of Research in IT \& Management, 2011: 61-77.

[8] Tom cox, Raymond Randall,Dr.Amanda Griffiths. interventions to control stress at work in hospital staff. Nottingham: HSE book s, 2002.

[9] U.Syed Aktharsha, H.Anisa. "Job stress and job satisfaction:An investigation of nursing personnel." JMINTERNATIONAL JOURNAL OF HR REVIEW, 2011: 18-32.

[10] wilkins, Kathryn. "work stress among health care providers." november 12, 2007. http://www.statcan.ca/english/freepub/82-003XIE/2006011/articles/10367-en.pdf (accessed october 14, 2012). 